\title{
Late Quaternary fluvial history of Santa Cruz Island, California, USA
}

\author{
R. Randall SchumanN ${ }^{1}{ }^{*}$ and JefFrey S. Pigati ${ }^{1}$ \\ ${ }^{1}$ United States Geological Survey, Denver, CO
}

\begin{abstract}
The geologic history of fluvial systems on Santa Cruz Island (SCI) is complex, involving responses to both allogenic and autogenic forcings. During periods of low or lowering sea level, canyons on the island were eroded and sediment was transported off the island onto the exposed marine shelf. When sea level rose, streams aggraded, building a sedimentary wedge that progressed from the shelf upstream into the canyons. This cycle of erosion and aggradation in response to glacial-interglacial sea-level cycles was likely repeated numerous times during the Quaternary, although clear evidence of only the most recent cycle is present in the island's alluvial sequences. Christy, Sauces, and Pozo Canyons contain thick packages of fine-grained sediments that were deposited as a result of the interaction between autogenic depositional processes and allogenic forcing of continuous base-level rise. Other canyons on the island either have little alluvial fill due to their steep gradients or are filled with coarse-grained, recent (likely late Holocene) alluvium that covers the older alluvial deposits. Differences in the nature and extent of the alluvial exposures on SCI relative to those on neighboring Santa Rosa Island reflect differences in the local topography, geology, and ranching histories of the 2 islands.
\end{abstract}

REsumen.-La historia geológica de los sistemas fluviales en la isla Santa Cruz (SCI, por sus siglas en inglés) es compleja, e involucra respuestas tanto a las fuerzas alogénicas como autogénicas. Durante los períodos en los que el nivel del mar disminuyó o estuvo en proceso de disminución, los cañones de la isla se erosionaron y el sedimento se transportó fuera de la isla, sobre la plataforma marina expuesta. Cuando subió el nivel del mar, las corrientes sufrieron agradación, formando una porción sedimentaria que avanzaba desde la plataforma río arriba hacia los cañones. Este ciclo de erosión y agradación en respuesta a los ciclos del nivel del mar glacial-interglacial probablemente se repitió en numerosas ocasiones durante el Cuaternario, aunque sólo hay evidencia clara del ciclo más reciente, presente en las secuencias aluviales de la isla. Los cañones Christy, Sauces y Pozo contienen cúmulos de sedimentos de grano fino que se depositaron como resultado de la interacción entre los procesos de sedimentación autogénicos y las fuerzas alogénicas de la continua elevación del nivel de base. Otros cañones de la isla, tienen poca cobertura aluvial debido a sus pronunciadas pendientes o están cubiertos de arena gruesa debido a los aluviones recientes (probablemente un Holoceno tardío) que cubren los antiguos depósitos aluviales. Las diferencias en cuanto a la naturaleza y al alcance de las exposiciones aluviales en la SCI en comparación a las de la isla vecina Santa Rosa reflejan diferencias en la topografía local, en la geología y en la historia de la ganadería.

Fluvial sediments can provide long-term records of the responses of river systems to both natural and anthropogenic influences. Alluvial deposition and erosion are driven primarily by changes in climate, which exerts controls on water and sediment availability, and base level, which affects the amount of energy available to a fluvial system for transporting its water and sediment load. Channel geometry, sediment load, and particle size are also affected by the geology of the substrate through which the river flows and by local topographic relief (e.g., Schumm and Brakenridge 1987,
Bull 1991). Another major forcing, tectonics, is important in many settings but probably had minimal influence on the river systems of Santa Cruz Island (SCI) over the last glacial-interglacial cycle due to the low tectonic uplift rate of the island (e.g., Muhs et al. 2014).

Rivers that terminate at the ocean are particularly interesting for study because sea level is their primary base level, so they respond more directly to changes in sea level than inland river systems. Rivers may adjust their width, depth, channel roughness, sinuosity,

*Corresponding author: rschumann@usgs.gov 
gradient, and/or channel pattern in response to base-level changes in order to achieve the required amount of energy to move water and sediment loads downstream (Mackin 1948, Schumm 1993). When channel patterns and/or hydraulic geometry changes are insufficient to compensate fully for the base-level change, rivers either incise or aggrade their beds.

During the Quaternary, mass transfer between oceans and continental ice sheets caused sea level to fluctuate by more than $100 \mathrm{~m}$ between glacial lowstands and interglacial highstands (Murray-Wallace and Woodroffe 2014). In our previous studies on Santa Rosa Island (SRI) (Schumann et al. 2016), we identified thick sequences of alluvial sediment resulting from aggradation driven by sea-level rise following the Last Glacial Maximum (LGM), which ended about $21 \mathrm{ka}$ ( $\mathrm{ka}=$ thousands of years ago). As sea level rose following the LGM lowstand, the sedimentary environment on SRI changed from an erosional regime to a dominantly depositional regime. Accumulation of sediment occurred first in channels and deltas on the island's offshore shelf, followed by aggradation that progressed upstream within the onshore canyons through cycles of channel filling and/or overbank flooding. This resulted in deposition of multiple fining-upward sequences of floodplain sediment, many of which are capped by paleosols of varying thickness and degree of development (Schumann et al. 2016). Autogenic fluvial processes (the internal workings of the system) interacted with the allogenic forcings (those external to the system), primarily rising base level, causing floodplain aggradation to be episodic rather than continuous. Periodic large storms (e.g., Behl 1995, Schimmelmann et al. 2003, Hendy et al. 2015) would likely have caused flooding, overbank deposition, and sporadic tributary rejuvenation, resulting in localized channel incision or deposition, thus adding further complexity to the sedimentary record. Local channel gradient and morphology, short-term climate variations, and autogenic controls also affected the timing and magnitudes of the episodic cut, fill, and flood episodes and are reflected in the number and thickness of aggradational sequences (Schumann et al. 2016).

Although these processes likely affected all of the Channel Islands simultaneously, there are significant differences between the alluvial deposits in the valleys of SCI and those on nearby SRI. In this study, we describe the alluvial deposits and depositional sequences in select drainages on SCI and attempt to identify the processes and factors responsible for creating them. We also evaluate the geology and on/offshore physiography of SCI to determine what influence these factors had on the alluvial response to the major external forcing of postglacial sea-level rise, as well as other events and processes that have modified the fluvial landscapes of the island. Finally, we examine the influence of vegetation stripping by sheep on the hillslopes and stream systems of SCI during the island's historical ranching period.

\section{Physical Setting}

Santa Cruz Island (SCI) is one of the group of 4 east-west aligned islands that make up the northern Channel Islands chain, located roughly $44 \mathrm{~km}$ south of Santa Barbara and $36 \mathrm{~km}$ southwest of Ventura, California. It is the largest of the 8 California Channel Islands (Fig. 1), measuring about $38 \mathrm{~km}$ long and $13 \mathrm{~km}$ wide, with an area of $250 \mathrm{~km}^{2}$. Elevations range from sea level to $747 \mathrm{~m}$ at Picacho Diablo, its highest point. The eastern part of Santa Cruz Island is part of Channel Islands National Park, whereas the western part of the island is managed by The Nature Conservancy.

The island has a maritime Mediterranean climate with cool, rainy winters and warm, dry summers. Average annual precipitation at the main ranch in the Central Valley is approximately $515 \mathrm{~mm}$, whereas along the coast the average rainfall is approximately $380 \mathrm{~mm}$ (Boyle and Laughrin 2000). Roughly $75 \%$ of the total annual precipitation falls during the winter months (December-March). Air temperatures on the island are generally between about 10 and $30^{\circ} \mathrm{C}$, although winter temperatures can fall below freezing and summer maxima can reach nearly $40{ }^{\circ} \mathrm{C}$ (Boyle and Laughrin 2000). Modern plant communities include coastal bluff, coastal sage scrub, island chaparral, grassland, and oak, maple, and pine woodlands (Junak et al. 1995). During the last glacial period and until approximately $12 \mathrm{ka}$, the climate of the region was cooler and wetter, supporting an extensive coastal conifer forest of pine, fir, and cypress (Anderson et al. 2008, 2010). 


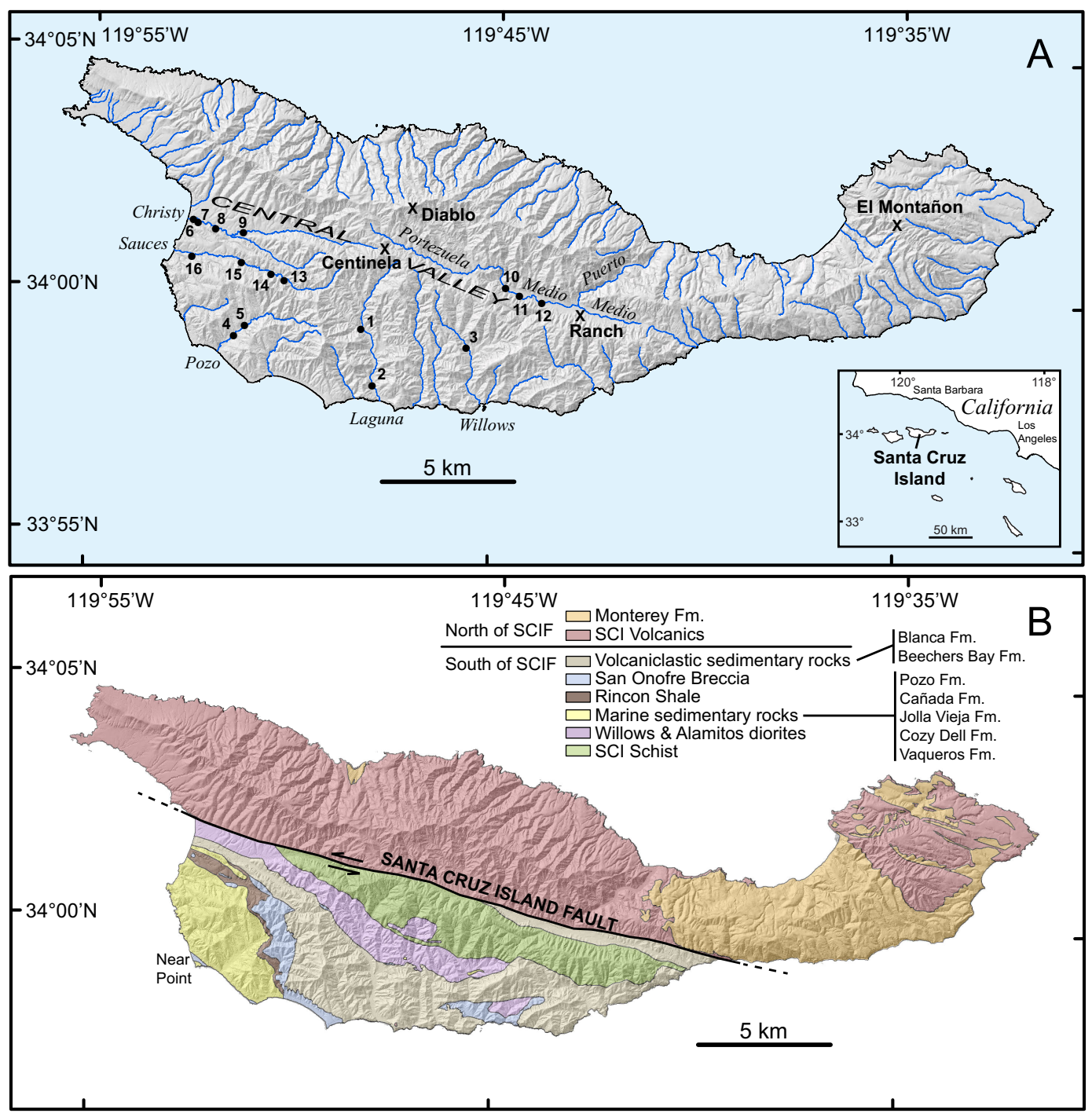

Fig. 1. (A) Map of Santa Cruz Island showing names of major drainages and physiographic features discussed in this report. Numbered black dots indicate locations of alluvial sections described and sampled by the authors. Only the sections in Christy and Sauces Canyons are discussed in this report. (B) Generalized bedrock geologic map of Santa Cruz Island (after Dibblee 2001a, 2001b). Surficial deposits including landslides and river alluvium are not shown. Only the primary strand of the Santa Cruz Island fault (SCIF) is shown here. Numerous other faults of small to intermediate size and displacement are also not shown.

Santa Cruz is the most rugged and topographically diverse of the northern Channel Islands. Its most prominent physiographic features are its 2 roughly east-west trending mountain ridges separated by the Central Valley (Fig. 1). The northern ridge stretches about $22 \mathrm{~km}$ from the island's west end to Cañada del Puerto and includes a number of peaks with elevations $>600 \mathrm{~m}$. The southern ridge spans approximately $20 \mathrm{~km}$ from east to west and is lower, with peaks reaching $450 \mathrm{~m}$ or less.

The Central Valley is unique among the Channel Islands. Its location between the 2 mountain ridges affords some isolation from the moderating influence of the Pacific Ocean, so the climate of the interior can be significantly different from that of other parts of the island. Because the valley is formed by the 
Santa Cruz Island fault (Fig. 1), it divides the island both topographically and geologically. The Central Valley is actually composed of the valleys of 3 distinct drainage systems. From the divide at Centinela (elevation $400 \mathrm{~m}$ ), Cañada Christy (also called Cañada Cervada) flows west toward the ocean, whereas Cañada de la Portezuela and Cañada del Medio flow eastward. Eastern and western branches of Cañada del Medio merge near the main ranch and flow northeastward to the ocean via Cañada del Puerto (Fig. 1).

The isthmus of the island is formed by a continuation of the island's northern ridge that reaches elevations as high as $550 \mathrm{~m}$, bounded on the east by a northwest-trending ridge called El Montañon (Fig. 1). The physiography of the easternmost part of SCI is formed largely by the heavily dissected remnants of uplifted ancient marine terrace surfaces that slope gently from inland to ocean and commonly terminate at steep, eroded sea cliffs.

\section{Geologic Setting}

The diverse geology of SCI comprises several rock types (Fig. 1), each with different levels of resistance to erosion. The "harder" volcanic, granitic, and metamorphic rocks form higher ridges and steeper, more rugged topography, whereas the "softer" sedimentary rocks form lower, more rounded hills or valleys. These differences are also reflected in the shapes of river valleys on the island and in the nature of the alluvial sedimentary deposits they contain.

The Santa Cruz Island fault (SCIF) is arguably the most prominent and significant geologic feature of the island. It is a nearvertically dipping, oblique-slip, left-lateral fault that displays significant lateral as well as vertical offsets. Lateral fault movement is evidenced by offset drainages, shutter ridges, and back-facing fault scarps that indicate significant activity during the late Quaternary (Pinter et al. 1998). Although the primary sense of movement of the SCIF is strike-slip, the much older rocks exposed south of the fault juxtaposed against younger rocks to the north indicate that significant vertical offset has occurred (Weaver 1969). However, offset of late Quaternary sediments indicates that the most recent relative vertical movement of the fault has been upward to the north (Pinter and
Sorlein 1991). Sedimentary evidence suggests that the most recent ground-rupturing seismic event along the SCIF occurred approximately $5 \mathrm{ka}$ (Pinter et al. 1998).

Distinctly different rock units are exposed to the north and south of the fault (Fig. 1). North of the fault, Miocene volcanic rocks of the Santa Cruz Island Volcanics are locally overlain in the isthmus and eastern part of the island by siliceous marine shales of the Miocene Monterey Formation. The volcanic rocks, which form the northern ridge of the island, consist of volcanic flows and breccias of rhyolite, dacite, andesite, and basalt (Gordon et al. 2001). These rocks are relatively hard and resistant to erosion, forming steep slopes and deep, $\mathrm{V}$-shaped valleys along the northern ridge of the island. The Monterey Formation consists of cream-colored, thinly bedded siliceous and tuffaceous shale of outer shelf to possible bathyal ocean floor environments (Weaver and Meyer 1969). The shales are relatively soft and easily erodible, forming rounded hilltops and broad ridge crests. Landslides are common on hillsides underlain by the Monterey Formation.

South of the fault, deep ocean basement rocks and intrusive igneous rocks of the island's core are exposed and are overlain in the southwestern part of the island by younger marine sedimentary rocks (Fig. 1). The oldest rock unit exposed on the island is the Santa Cruz Island Schist, a chlorite schist, or "greenschist," composed of metamorphosed volcanic and sedimentary rocks and minor altered plutonic rocks. Its age is unknown, but because it is intruded by the Late Jurassic Willows Diorite it is considered to be pre-Jurassic (Gordon et al. 2001). This relatively resistant rock forms the core of the southern ridge of the island (Fig. 1). The Willows Diorite consists primarily of dark to medium gray hornblende gabbro, hornblende diorite, and quartz diorite, intrusive igneous rocks that are similar in composition to volcanic basalt (Gordon et al. 2001). Also included in this map unit is the Late Cretaceous Alamitos Tonalite, a quartz diorite that is lighter in color and slightly less mafic than the Willows Diorite.

Paleocene to early Miocene-aged marine sedimentary rocks are exposed in the southwestern part of the island (Fig. 1). This map unit consists of the Pozo, Cañada, Jolla Vieja, Cozy Dell, and Vaqueros Formations. They 
TABLE 1. Locations of alluvial sections (see Fig. 1 for map). Although we collected samples for radiocarbon dating from sections in other canyons, only samples from Christy and Sauces Canyons were processed. Radiocarbon ages for section 16 are from Pinter et al. (2011).

\begin{tabular}{|c|c|c|c|c|c|}
\hline Section & Canyon & Latitude & Longitude & Sampled? & Notes \\
\hline 1 & Laguna & 33.98765 & -119.80404 & $\mathrm{Y}$ & \\
\hline 2 & Laguna & 33.96828 & -119.79878 & $\mathrm{Y}$ & \\
\hline 3 & Willows & 33.98192 & -119.76036 & $\mathrm{~N}$ & \\
\hline 4 & Pozo & 33.98433 & -119.85638 & $\mathrm{Y}$ & $\begin{array}{l}\text { Same as Pozo } 3 \text { in } \\
\text { Glassow et al. (2009) }\end{array}$ \\
\hline 5 & Pozo & 33.98800 & -119.85255 & $\mathrm{Y}$ & $\begin{array}{l}\text { Same as Pozo Trib } 1 \text { in } \\
\text { Glassow et al. (2009) }\end{array}$ \\
\hline 6 & Christy & 34.02358 & -119.87438 & $\mathrm{Y}$ & \\
\hline 7 & Christy & 34.02283 & -119.87233 & $\mathrm{Y}$ & \\
\hline 8 & Christy & 34.02064 & -119.86497 & $\mathrm{Y}$ & \\
\hline 9 & Christy & 34.01895 & -119.85356 & $\mathrm{Y}$ & \\
\hline 10 & Medio & 34.00303 & -119.74480 & $\mathrm{~N}$ & \\
\hline 11 & Medio & 34.00028 & -119.73897 & $\mathrm{~N}$ & \\
\hline 12 & Medio & 33.99810 & -119.72968 & $\mathrm{~N}$ & \\
\hline 13 & Sauces & 34.00364 & -119.83631 & $\mathrm{~N}$ & \\
\hline 14 & Sauces & 34.00550 & -119.84171 & $\mathrm{Y}$ & \\
\hline 15 & Sauces & 34.00933 & -119.85402 & $\mathrm{Y}$ & \\
\hline 16 & Sauces & 34.01109 & -119.87457 & $\mathrm{~N}$ & $\begin{array}{l}\text { Same section as Fig. } 3 \\
\quad \text { in Pinter et al. }(2011)\end{array}$ \\
\hline
\end{tabular}

are tan to brown, fine- to coarse-grained sandstones, siltstones, conglomerates, and gray shales. Conglomerate clasts include pebbles and cobbles of metamorphic, volcanic, and plutonic rocks. These rocks were deposited in shallow-water shelf to bathyal environments (Gordon et al. 2001). The Miocene Rincon Shale overlies the Vaqueros Formation. It is composed of gray to brown clayey shale and mudstone. Slopes of Rincon Shale are easily eroded and subject to landslides and soil slips (Dibblee 2001a). The Rincon Shale is, in turn, overlain by the Miocene San Onofre Breccia, consisting of shallow-water marine conglomerate, sandstone, and mudstone that contain clasts of dacite porphyry, quartzite, garnet amphibolite, blueschist, and volcanic and sedimentary rocks, indicating that it is derived from local sources (Gordon et al. 2001). It is weakly indurated and easily eroded (Dibblee 2001a).

The rock unit labeled "volcaniclastic sedimentary rocks" on Figure 1B consists of the Blanca Formation and Beechers Bay Formation. The Blanca Formation consists of light gray to buff, thick-bedded volcaniclastic conglomerate, tuffaceous sandstone, tuff breccia, and rhyolite and andesite tuff of middle Miocene age (Dibblee 2001a, Gordon et al. 2001). These sediments were deposited in a shallow shelf or basin-margin environment adjacent to active pyroclastic volcanism, per- haps as a submarine fan (Gordon et al. 2001). Rocks of the Blanca Formation are resistant to erosion and form prominent topographic highs with steep valley walls or sea cliffs (Weaver et al. 1969). The Miocene Beechers Bay Formation is exposed in a section at Near Point (Fig. 1B). It is composed of light-colored and thinly bedded siltstone, fine-grained sandstone, and conglomerate that was deposited in an outer shelf or upper-slope marine environment, and it is considered stratigraphically equivalent to the Blanca Formation (Weaver et al. 1969).

\section{Field and Laboratory Methods}

Exposures of alluvial fill in canyons on western Santa Cruz Island (Fig. 1) were investigated during several visits to the island between 2014 and 2016. The location of each section was accurately determined by Global Positioning System (GPS) methods (Table 1), and each section was measured, photographed, sketched, and described. Samples of bulk sediment and, where available, discrete fragments of charcoal, were collected from selected horizons for radiocarbon age determination.

Bulk organic matter and charcoal samples were submitted to the U.S. Geological Survey (USGS) radiocarbon laboratory in Reston, Virginia, for radiocarbon $\left({ }^{14} \mathrm{C}\right)$ dating. Both types 


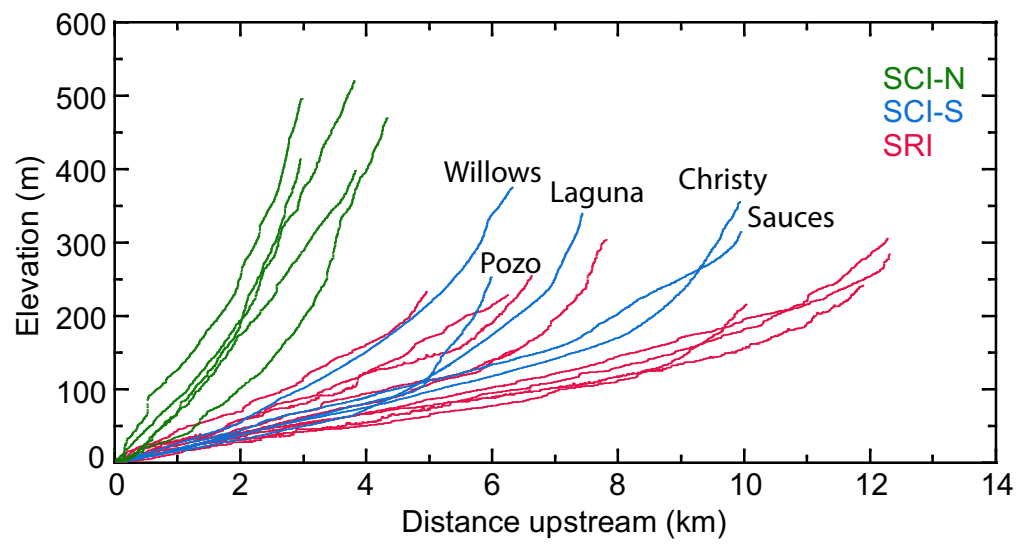

Fig. 2. Longitudinal profiles of streams on Santa Cruz and Santa Rosa Islands. SCI-N = drainages flowing northward from the north ridge of Santa Cruz Island. SCI-S = drainages flowing southward. Profiles of specific drainages discussed in this report are labeled. SRI = drainages on Santa Rosa Island. Red-colored profiles on the left side of the graph drain southward, whereas those to the right drain northward.

of samples were subjected to the standard acid-base-acid (ABA) treatment, and the basesoluble fraction was combusted under vacuum in the presence of $\mathrm{CuO}$ and $\mathrm{Ag}$. Humic acids were collected as the base-soluble fraction of the sample material, filtered through a 0.45 $\mu \mathrm{m}$ Metricel membrane filter, and then acidified in $1 \mathrm{~N} \mathrm{HCl}$. The precipitated humic acids were then neutralized in ultrapure water, isolated by centrifuge, dried in an oven overnight at $70{ }^{\circ} \mathrm{C}$, and combusted as above.

The resulting sample $\mathrm{CO}_{2}$ was converted to graphite using an $\mathrm{Fe}$ catalyst and the standard hydrogen reduction process. Graphite samples were pressed into targets and submitted to the Center for Accelerator Mass Spectrometry (CAMS) at Lawrence Livermore National Laboratory for ${ }^{14} \mathrm{C}$ analysis. For most samples, a second aliquot of $\mathrm{CO}_{2}$ was isolated and submitted to the Stable Isotope Laboratory, University of California, Davis, for $\delta^{13} \mathrm{C}$ analysis in order to correct the measured ${ }^{14} \mathrm{C}$ activity of the samples for isotopic fractionation. All ${ }^{14} \mathrm{C}$ ages were calibrated to calendar ages using the IntCal13 data set and CALIB 7.1 (Stuiver and Reimer 1993, Reimer et al. 2013). Ages from this study are presented in thousands of calibrated years before present $(\mathrm{YBP} ; 0 \mathrm{YBP}=$ $1950 \mathrm{AD} ; \mathrm{ka}=$ thousands of calibrated ${ }^{14} \mathrm{C}$ YBP), and uncertainties are given at the 95\% $(2 \sigma)$ confidence level. Ages from other sources are reported as published.

Digital representations of topography and river long profiles were extracted from a $1-\mathrm{m}$ resolution LiDAR-based digital elevation model (DEM) of the Channel Islands (USGS Channel Islands ARRA LiDAR Project). Bathymetry data for the northern Channel Islands platform are from the National Oceanic and Atmospheric Administration's (NOAA) Coastal Inundation Project (Carignan et al. 2009). Data from both sources were processed with Blue Marble Geographics' Global Mapper (Hallowell, ME) and Environmental Systems Research Institute's ArcGIS software (Esri, Redlands, CA) to develop shaded relief images of topography and bathymetry contours. ArcHydro tools were used within ArcGIS to infer drainages from the DEM data and extract distance/ elevation data for stream profiles.

\section{Results and Discussion \\ Channel Gradients}

The morphologies of river valleys in different parts of Santa Cruz Island range from deep, steep-walled arroyos to broad, shallow, sandy and gravelly washes. These differences are controlled largely by underlying rock type and topographic relief. One readily comparable expression of relief is the longitudinal profile of a stream channel (Fig. 2). The valleys of streams draining northward from the north ridge have steep gradients, steep valley sides, and narrow valley bottoms, and contain little alluvium, so we did not investigate them further. Valleys draining southward from the south ridge are generally broader, with longer 
and gentler side slopes, wider valley bottoms, and gentler stream gradients. In contrast, Christy, Sauces, and Pozo Canyons in the western part of the island have the gentlest gradients on SCI (Fig. 2). Steeper channels generally are able to transport coarser-grained and larger amounts of sediment downstream for a given discharge, which explains why there is little alluvium in the channels north of the north ridge, mostly coarse-grained sediments south of the south ridge, and thicker and more continuous fine-grained alluvial deposits in Christy, Sauces, and Pozo Canyons. Notably, gradients of the south- and west-draining streams on SCI are similar to those on nearby SRI (Fig. 2).

\section{Character and Ages of Alluvial Deposits}

In Laguna and Willows Canyons (Fig. 1), the valley floors are covered to an unknown depth with recent (likely late Holocene) coarse-grained alluvium. In the upper reaches of the canyons, subangular pebbles and cobbles of schist, diorite, and volcanic rocks are set in a matrix of medium to coarse sand. These rocks erode to coarse sand and larger clasts, forming deposits that are generally not cohesive enough to maintain stable, deep arroyos. When the coarse-grained alluvium is incised, the arroyo walls tend to collapse and their sediments are reworked into the valley floor, forming a broad alluvial wash rather than a deep, steep-walled arroyo. The broad streambed resembles that of a braided or meandering stream with braid bars or midchannel bars around which the intermittent streams flow during wet periods. In some locations, the stream has incised these deposits to a depth of 1-3 m. Downstream, the streams flow over more easily erodible tuffaceous sandstones, siltstones, and conglomerates of the Blanca Formation (Fig. 1), and the alluvium is somewhat finer grained, consisting primarily of silt to coarse sand with lesser, but still significant, components of pebble to cobble material from upstream. Minimal recent incision has taken place in the lower reaches of these streams, so the streambeds consist of an unknown thickness of alluvium forming broad sandy and gravelly washes. Because of the high-energy fluvial environment, probable reworking of sediments during floods, and minimal incision, the potential for preservation and/or exposure of older alluvial sediments containing datable materials such as charcoal or shells is minimal.

The lower two-thirds of Cañada Pozo is underlain by marine sandstone, siltstone, and shale bedrock that is more easily erodible than the volcanic and plutonic rocks upstream. Pebbles and cobbles in the alluvium of Cañada Pozo have eroded primarily from conglomerates in the Blanca Formation and San Onofre Breccia that are exposed in the upper part of the canyon (Fig. 1). The valley floor has a wide arroyo (approximately 10 to $60 \mathrm{~m}$ wide) that is bounded on both sides by vertical walls ranging from about $6 \mathrm{~m}$ high in the upstream part of the canyon to 1-2 $\mathrm{m}$ high near the mouth. The relict floodplain sediments exposed in the arroyo walls consist of grayish-tan, buff, or light brown fine sandy silt and occasional pebble layers, with multiple paleosols indicated by darker gray, relatively organic-rich horizons. The finer-grained alluvium in the arroyo walls of Cañada Pozo also contains several discrete Chumash shell midden layers. The oldest of these, located about a meter above the currently active streambed, has been dated to approximately 4800 cal BP (Glassow et al. 2009).

In many locations, a 0.5 - to 1.5 -m-thick layer of gravelly, silty, sandy alluvium and colluvium caps the finer-grained alluvium. This top stratum, called "postsettlement alluvium" (PSA), was likely deposited in the late 1800 s as a result of overgrazing by sheep followed by intense floods and hillslope erosion (Fig. 3; Brumbaugh 1980, Perroy et al. 2012). Older alluvium may be preserved under the valley floor sediment, but either the channel did not incise deeply enough to expose it or the streambed has been partially refilled with reworked Holocene alluvium and/or PSA, burying the older sediments. Perroy et al. (2012) estimated that at least $0.5 \mathrm{~m}$ of aggradation has occurred in the channel at their site Pozo 1, located about $400 \mathrm{~m}$ upstream of the coast, since initial arroyo incision. Upstream of Pozo 1, however, their measurements indicated continuing incision during the same period.

Cañada de los Sauces and Cañada Christy are the only other drainages on Santa Cruz Island with deep arroyos exposing long records of alluvial deposition. The alluvial sections in Cañada Christy generally consist of coarse sand and gravel in the lower parts, overlain by clayey and silty sand to clayey silt 


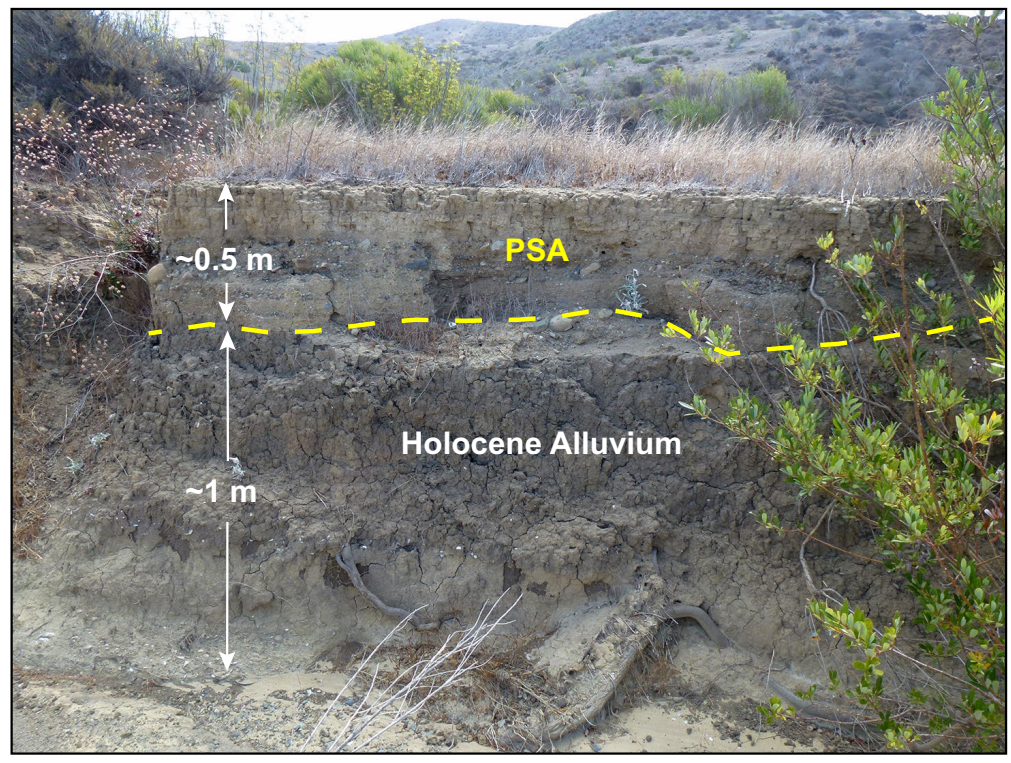

Fig. 3. Exposure of sediment in Cañada Pozo showing the postsettlement alluvium (PSA) layer overlying Holocene alluvium.

with paleosols and interspersed thin layers of gravel (Figs. 4, 5). Some of the cobble layers are imbricated, whereas others appear randomly oriented within a finer-grained matrix, indicative of debris flows. The finer-grained terrace fill typically consists of horizontal to subhorizontal alternating lighter and darker beds of sediment of varying thickness, with occasional beds or lenses of pebbles and cobbles. The darker beds generally contain silty clay or clay and organic matter, whereas the lighter-colored beds are composed primarily of silt and sand and appear to contain less organic matter. The darker sediments probably represent paleosols that developed during periods of floodplain stability, whereas the lighter sediments are interpreted as floodplain aggradational deposits. Channel-fill sequences containing sand and gravel are locally found cutting into the floodplain deposits. Some discrete beds can be traced up- or downstream for hundreds of meters, but in other locations the sedimentary sequences appear to be quite localized. Burned layers or lenses consisting of dark brown to black clay or silt, sometimes with reddish-orange (oxidized) layers or streaks, are relatively common in the lower parts of sections. Obvious PSA layers, which are distinct and common in Cañada Pozo, were not observed at the tops of the sections we studied in Cañada Christy.

Alluvium in Cañada de los Sauces is generally finer grained than in Cañada Christy, probably due in part to the canyon being underlain by more easily erodible marine sedimentary rocks. The alluvium generally consists of tan to brown clayey silt with multiple paleosols. However, thin to occasionally thick gravel layers were noted in all the sections we described, as well as in the modern streambed. Burned layers and lenses are less common than in Cañada Christy, and a PSA layer up to $1 \mathrm{~m}$ thick caps the section in many areas, as shown at the top of section 14 (Figs. 4, 5).

Ages of the alluvial strata generally increase with depth in each section (Fig. 4). The oldest alluvium observed in this study is a burned layer about $2 \mathrm{~m}$ above the base of section 7 in Cañada Christy, dated to 34.7 ka (Fig. 4, Table 2). Strata at the base of section 16 in Cañada de los Sauces vielded an age of $18.1 \mathrm{ka}$ (Fig. 4; Pinter et al. 2011). Bedrock is exposed in the active channel at or near sections 7 and 16 , indicating that the true base of the alluvial section is exposed at those sections. Upstream of these exposures in both canyons, the active streambed is underlain by an unknown thickness of alluvium, indicating that the arroyos 

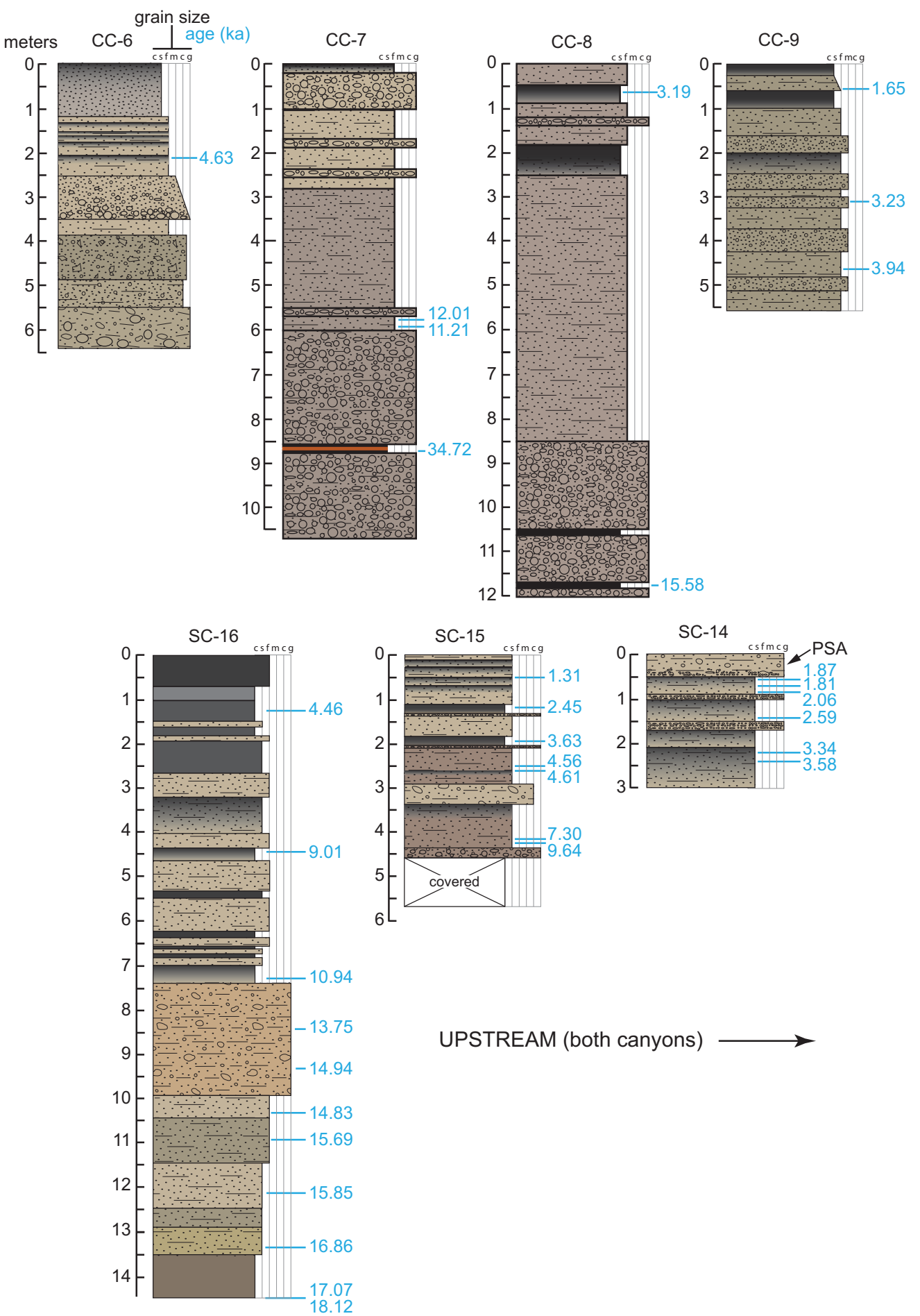

UPSTREAM (both canyons)

Fig. 4. Stratigraphic sections of alluvial deposits in arroyo walls in Cañada Christy (CC) and Cañada de los Sauces (SC). The grain size scale to the right of each section is labeled as follows: clay, silt, fine sand, medium sand, coarse sand, gravel (c s f m c g). Numbers in blue indicate ages—in calibrated thousands of ${ }^{14} \mathrm{C}$ years before present $(\mathrm{ka})$ - of charcoal and carbonized wood samples collected from each section; see Table 2. Section SC-16 description and radiocarbon ages are from Pinter et al. (2011). PSA = postsettlement alluvium. 

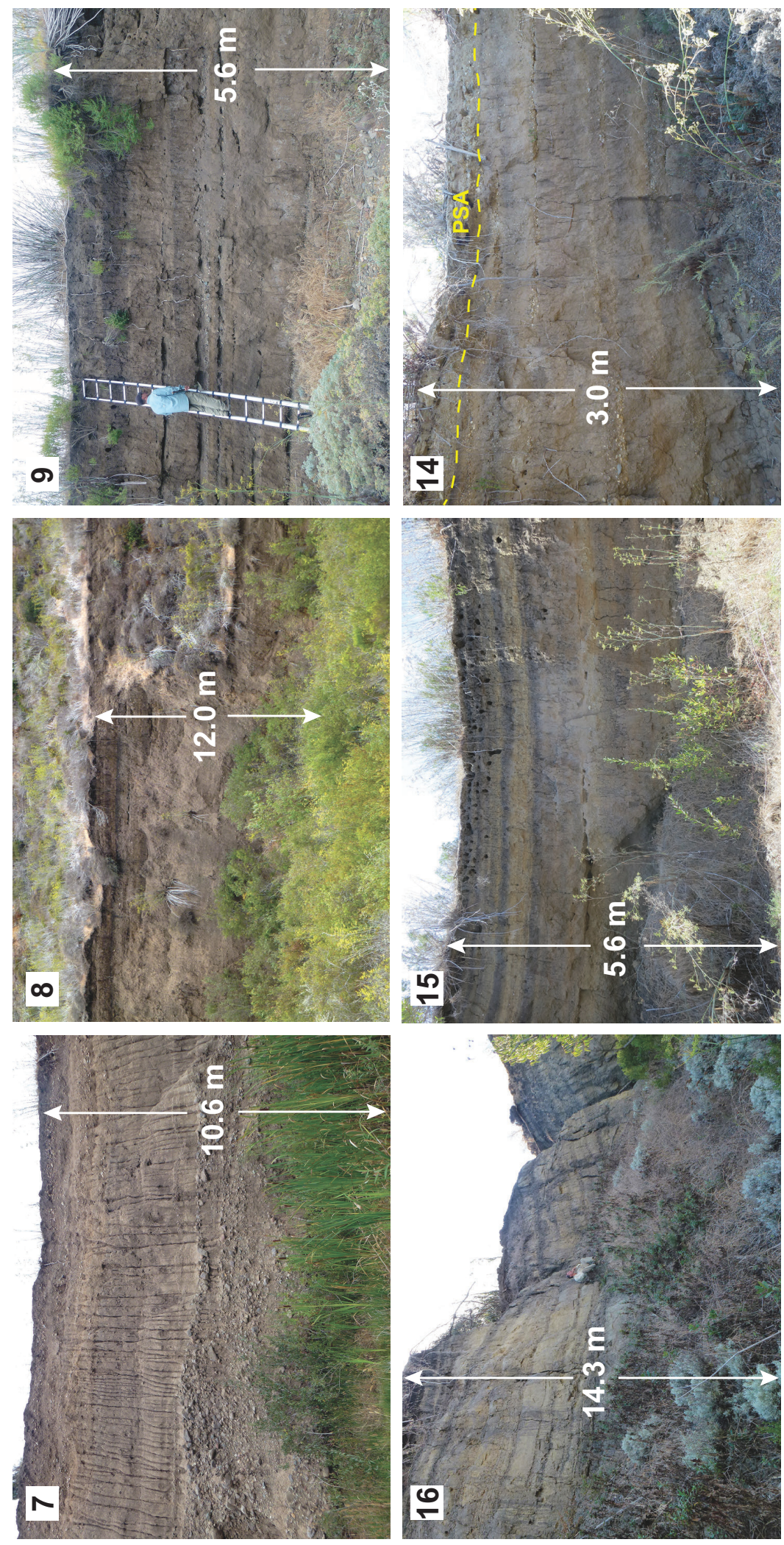






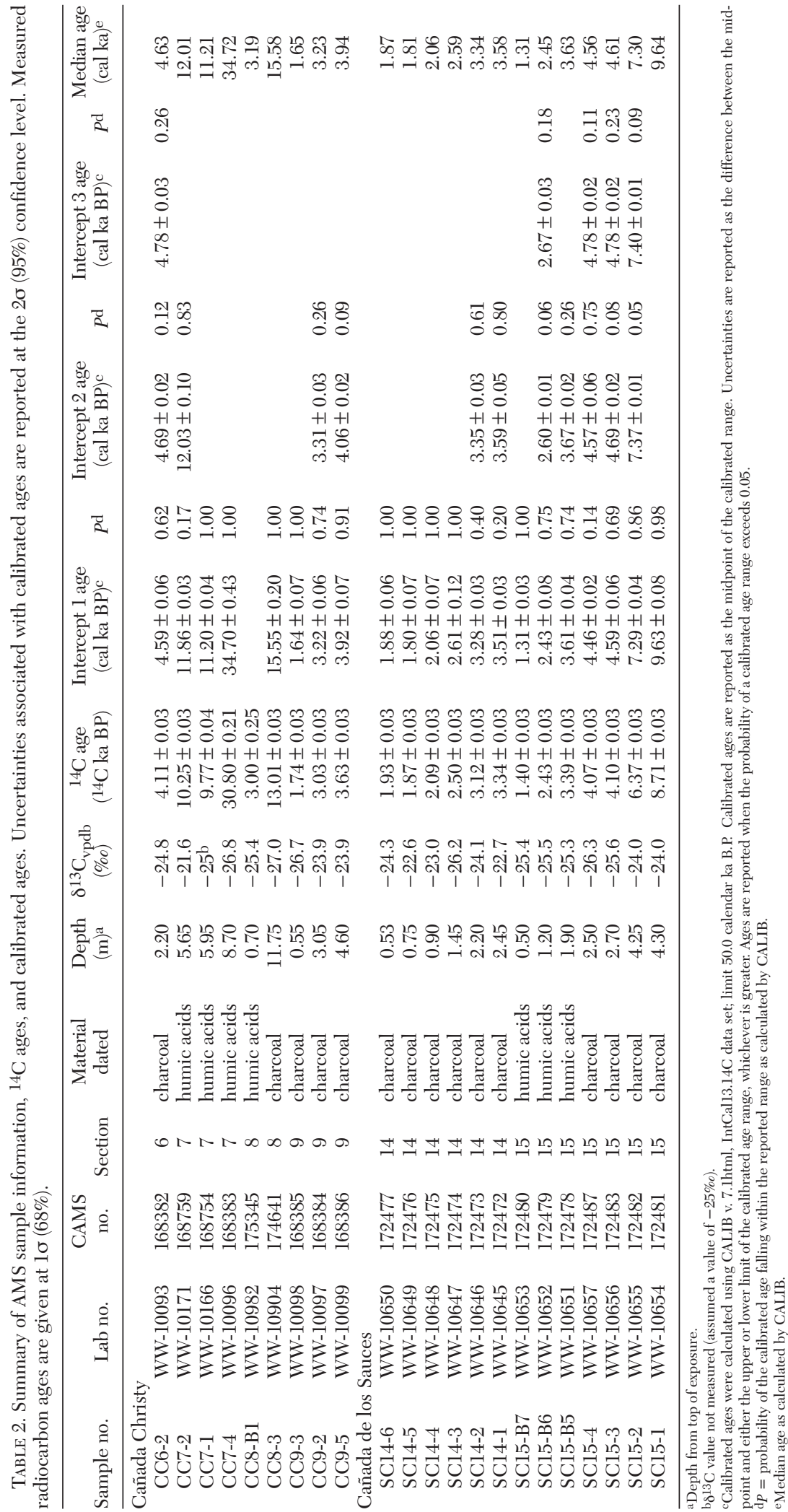


did not incise the alluvium to bedrock, and/or that aggradation of the streambed occurred subsequent to arroyo cutting. Except for section 8, arroyo depth decreases progressively upstream in both canyons (Fig. 4).

The ages of the uppermost sediment in each section are also significant because they indicate when base-level-driven aggradation ceased in each part of each canyon. Ages of the upper $1 \mathrm{~m}$ or less of alluvium range from approximately $4.5 \mathrm{ka}$ in section 16 to younger than 2 ka in sections 9, 14, and 15 (Fig. 4). We were not able to sample the uppermost strata of section 7 , but at section 6 , approximately $200 \mathrm{~m}$ downstream, $2 \mathrm{~m}$ of sediment aggraded after approximately 4.6 ka (Fig. 4).

\section{Paleoshoreline Reconstruction and Shelf Sedimentation}

Sea level is the local base level for Santa Cruz Island's river systems, and therefore, fluctuations of sea level exert strong control on the timing and processes of erosion and aggradation. Eustatic sea level varied from as much as $8 \mathrm{~m}$ above present during the last interglacial period about $120 \mathrm{ka}$ (Muhs et al. 2011), to as much as $135 \mathrm{~m}$ below present sea level at the LGM about $21 \mathrm{ka}$ (Yokoyama et al. 2000, Clark and Mix 2002, Peltier and Fairbanks 2006). However, sea level at any specific location, called relative sea level (RSL), is also influenced by local or regional isostatic, tectonic, and gravitational forces, such as loading or unloading of the Earth's crust by the addition or removal of ocean water or glacial ice. These local or regional departures from eustasy have been termed glacial isostatic adjustment (GIA) effects (Milne and Mitrovica 1996, 2008, Mitrovica and Milne 2003).

An RSL curve that incorporates adjustments for GIA effects has been modeled for the northern Channel Islands (Clark et al. 2014). This curve was used with a DEM of bathymetric data to estimate the locations of paleoshorelines around SCI at various times as sea level rose from its local LGM minimum to its present level (Fig. 6). When local sea level was at its LGM lowstand of $-106 \mathrm{~m}$, most of the shelf surrounding SCI was exposed. To the north of SCI, this caused channel lengths to increase to more than double their highstand lengths. To the south, the shelf surrounding the island is narrower, but most channels were significantly lengthened as well.
The lowered base level caused streams to incise and erode in the uplands, transporting large amounts of sediment down the exposed shelf to the paleoshoreline (Fig. 6), forming large "shelf-edge" or "lowstand" deltas (e.g., Suter and Berryhill 1985, Posamentier et al. 1992, Porebski and Steel 2006).

Topographic profiles across the island shelf suggest the extent of delta sediment at the shelf edge and show the dramatic flattening of the outer shelf surface to the north of SCI and SRI (Figs. 7, 8). Data from seismic-reflection surveys conducted around the northern Channel Islands (Junger 1979) clearly show the presence and extent of the lowstand delta deposits, not only from the LGM lowstand but also from previous glacial lowstands (Fig. 8; Pinter et al. 2003). The significance of the shelf-edge deltas is twofold: (1) the deltas represent large amounts of sediment that have been removed from the island's valleys and transported offshore, and (2) the wedges of deltaic sediment, built over multiple glacialinterglacial cycles, have substantially modified the topography of the outer shelf around the northern Channel Islands, which affects paleoshoreline position, as well as the timing and progression of aggradation during each postglacial transgressive stage. North of the western end of SCI (WSCI in Fig. 7), for example, the shoreline transgressed approximately $4 \mathrm{~km}$ between 20 and $15 \mathrm{ka}$ across the nearly horizontal upper surface of the delta deposits (Fig. 8). North of the mouth of Cañada Diablo, the flat upper surface of the delta wedge stands at -85 to $-87 \mathrm{~m}$, so at $-90 \mathrm{~m}$, the paleoshoreline was still basinward (north) of the outer edge of the delta (Fig. 8). The shoreline here moved only a few hundred meters landward in the same 5000-year period, shown by the close spacing of the $-106-\mathrm{m}$ and $-90-\mathrm{m}$ contours in Figure 6. Then, between 15 and $10 \mathrm{ka}$, the shoreline north of Cañada Diablo transgressed rapidly across the shelf, covering a distance of nearly $5 \mathrm{~km}$, while the shoreline north of western SCI transgressed approximately $1.7 \mathrm{~km}$ during the same period.

The shelf-edge delta complex extends to the north of Santa Rosa Island as well, exemplified by the profile extending northwest of Cañada Verde (Figs. 7, 8). Because the shelf is much broader around SRI than SCI, the wedge of deltaic sediment occupies a much 


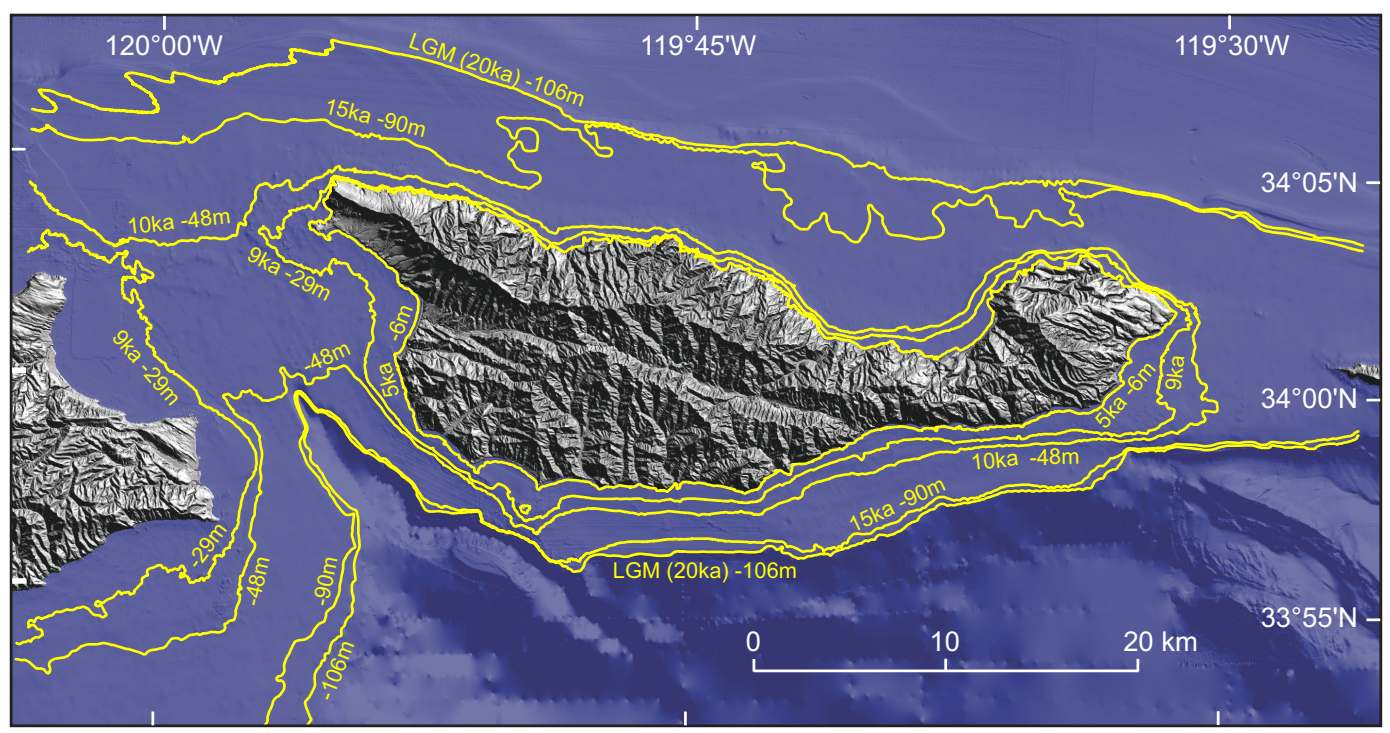

Fig. 6. Map of Santa Cruz Island and surrounding offshore area, showing estimated paleoshorelines at 20, 15, 10, 9, and $5 \mathrm{ka}$. Sea level data are from Clark et al. (2014). Bathymetry data are from Carignan et al. (2009).

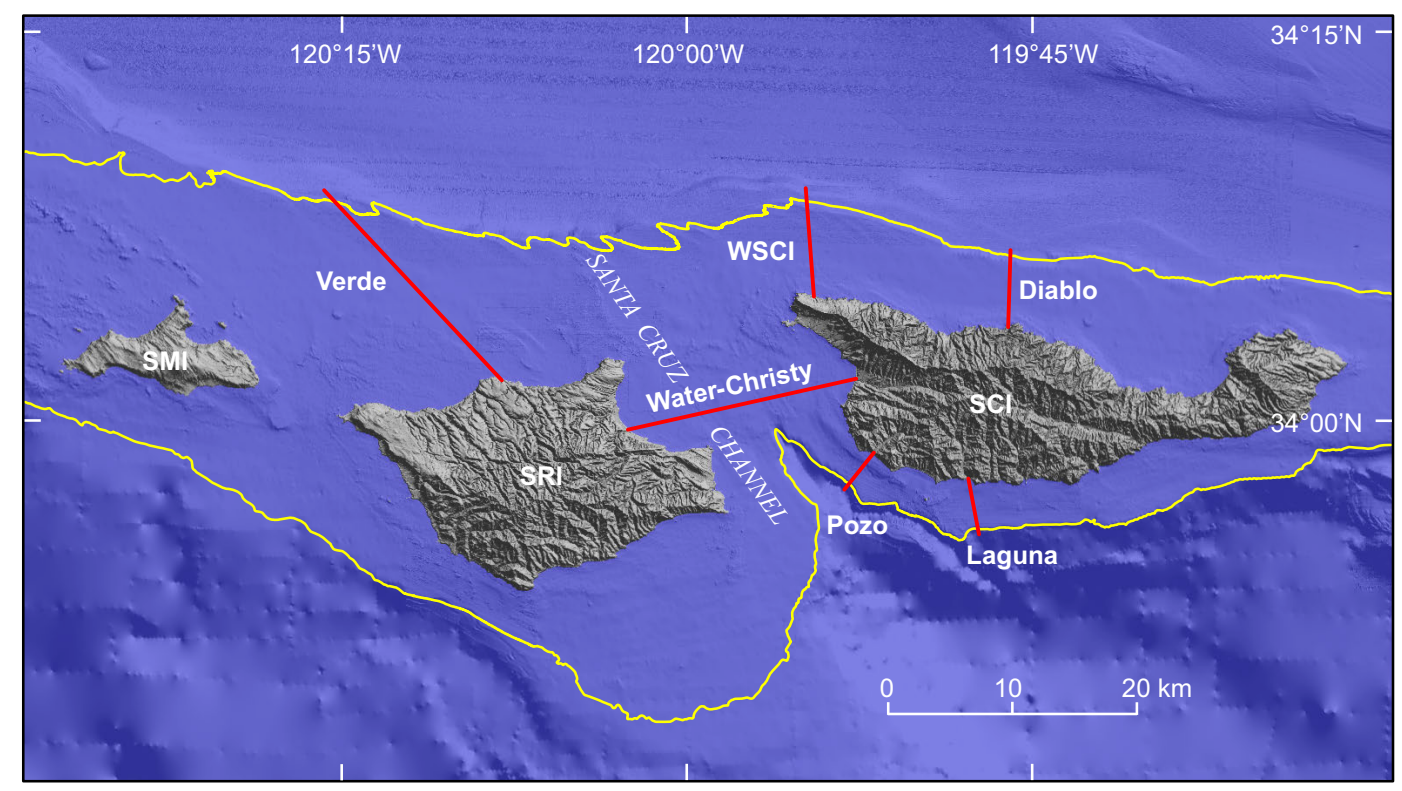

Fig. 7. Map of the northern Channel Islands and surrounding marine shelf. SCI $=$ Santa Cruz Island, SRI = Santa Rosa Island, SMI = San Miguel Island. The yellow line denotes the LGM paleoshoreline. Red lines show positions of topographic profiles across the shelf, named for the canyon at which each profile originates. WSCI $=$ western Santa Cruz Island.

smaller portion of the shelf north of SRI (note the different horizontal scales of the shelf profiles for SCI and SRI in Fig. 8). South of SCI, there do not appear to be thick wedges of delta sediment at the shelf edge (Fig. 8), suggesting that due to the narrower width and steeper gradient of the shelf, much of the alluvium from south-draining canyons may 



Fig. 8. Topographic profiles across the shelf surface adjacent to Santa Cruz and Santa Rosa Islands. Locations of profiles are shown in Figure 7. Note the horizontal scale change between the upper 4 and lower 2 profile graphs. Dashed lines denote the inferred wedge of shelf-edge delta sediments. The inset shows the seismic reflection profile of the marine shelf edge north of western Santa Cruz Island. Colored areas denote sediment packages interpreted as fluvial delta deposits associated with specific sea-level lowstands, as labeled. Marine oxygen isotope stage (MIS) 2 refers to the Last Glacial Maximum. The inset figure was modified from Pinter et al. (2003).

have been transported over the shelf edge and into the deeper Santa Cruz Basin.

Christy and Sauces Canyons, as well as Water and Cherry Canyons on SRI, drain into a shallow basin in the Santa Cruz Channel between SRI and SCI (Figs. 6, 7, 8). Analysis of the subtle topography of the strait (Fig. 8), which reaches only $-45 \mathrm{~m}$ depth, suggests that streams from both islands drained into the basin, which in turn drained southward 
into a deep submarine canyon (Fig. 6). The extremely gentle slope and shallow depth of the basin is likely responsible for preventing the pre-LGM sediment in section 7 in Cañada Christy from being scoured. The strait would have been subaerially exposed from approximately $70 \mathrm{ka}$ to $10 \mathrm{ka}$, and the shallow basin may have acted as a local base level, essentially insulating Cañada Christy and Cañada de los Sauces from some of the effect of the falling sea level during that period.

\section{Fluvial System Response to Sea-Level Change}

The period of falling sea level between the end of the last interglacial highstand at about $80 \mathrm{ka}$ and the last glacial lowstand at about 25-21 ka was marked largely by erosion and incision in the uplands. The magnitude and duration of falling sea level during this period would have been sufficient for nearly all alluvium in the canyons to have been transported out and onto the shelf, although remnants of pre-LGM alluvium are locally preserved. In Cañada Christy, a charcoal fragment from a burned layer near the base of section 7 yielded a calibrated radiocarbon date of 34.7 ka (Fig. 4, Table 2) and the next higher-dated stratum in the section is 11-12 ka (Fig. 4). The presence of sediment deposited during a very minor intermediate highstand (approximately $35-30 \mathrm{ka}$ ) that punctuated a longer period of otherwise continuously falling sea level between 60 and $20 \mathrm{ka}$ is somewhat unusual. Because the channels would have partially adjusted their gradients by increasing or decreasing sinuosity in response to changing base level (Schumm and Brakenridge 1987, Schumm 1993), older alluvium could have been abandoned, covered, and preserved by channel shift during the regressional stage. Pockets of older alluvium may also have been preserved behind obstructions such as bedrock protrusions. In any case, it is doubtful that Cañada Christy was continuously aggrading between 35 and $12 \mathrm{ka}$. The contact between the older cobbly-gravelly alluvium and younger sandy-silty alluvium at a depth of about $6 \mathrm{~m}$ in section 7 (Figs. 4, 5), if not erosional, likely records at least a hiatus in deposition. Unfortunately, we found no datable material in the uppermost strata of the coarse-grained part of the section to verify this.
After the LGM lowstand, sea level rose relatively rapidly, triggering a shift in the dominant fluvial process on SCI from erosion to deposition. Accumulation of sediment occurred first through vertical and lateral accretion in broad, shallow channels on the shelf. The gradient of the shelf determined the extent of fluvial channel shortening relative to shoreline advance, but sediment availability also controlled the rate at which aggradation progressed upstream across the shelf, and later, within the canyons.

The rate at which sedimentation progressed upstream appears to have been considerably faster than the rate of sea-level rise. The oldest calibrated ${ }^{14} \mathrm{C}$ age from a fragment of charred wood near the base of section 16 in Cañada de los Sauces is about $18 \mathrm{ka}$ (Pinter et al. 2011). Bedrock is exposed near the channel floor at sections 7 and 16, both of which are within $0.5 \mathrm{~km}$ of the present shoreline (Fig. 1), so it is reasonable to assume that the oldest sediment at the base of these alluvial sections indicates the initiation of aggradation in these canyons. However, as discussed above, the onset of post-LGM aggradation in Cañada Christy is more difficult to determine from the available data.

After about $11 \mathrm{ka}$, the alluvium in sections 7 and 16 became generally finer grained and it appears that sediment accumulated more rapidly than before. This change roughly corresponds to the time at which the Santa Cruz Channel between SRI and SCI was inundated (note the positions of the $10 \mathrm{ka}$ and 9 ka shorelines between the islands in Fig. 6), dramatically shortening channel lengths, particularly those of Christy and Sauces Canyons. Section 8 in Cañada Christy also appears to exhibit a similar fining of the alluvium sometime after 11-12 ka (Fig. 4).

By $5 \mathrm{ka}$, sea level was only $6 \mathrm{~m}$ below present, and the rate of sea-level rise was much slower than during the early Holocene. As sea level stabilized, the rate of aggradation would have decreased, though likely with a time lag as the effects of the change propagated upstream. Paleosols are thicker and more abundant in the upper parts of the sections (Figs. 4, 5), suggesting longer periods of floodplain stability between overbank depositional events. No longer under the driving influence of continuing base-level rise, the stream systems would have naturally reached a point at which 
aggradation would ultimately cease, followed by arroyo incision as the systems adjusted to the relative stability of modern sea level (Schumm 1977). Ages of the uppermost alluvial layers in arroyos of SCI (Fig. 4) suggest that aggradation ceased in the lower reaches of drainages between 4 and $3 \mathrm{ka}$, and in the upper reaches at about $1 \mathrm{ka}$ or later.

\section{Allogenic vs. Autogenic Processes}

River system dynamics are controlled by both allogenic (external to the fluvial system, such as sea-level rise) and autogenic (the internal workings of the system) forcings that may interact on concurrent or different temporal and spatial scales. These responses are often complex, making simple cause-andeffect relations between external forcings and fluvial system responses difficult to determine. Nevertheless, through careful examination of the alluvial stratigraphy in the canyons of SCI, we find multiple examples of autogenic cyclic deposition overprinted on deposition driven by allogenic forcings, primarily rising sea level.

As sea level rose, channel pattern adjustment was insufficient to compensate for the rapid rate and large magnitude of base-level change, resulting in aggradation. The episodic nature of the aggradation is indicated by the multiple depositional sequences in the alluvial fills of each drainage (Figs. 4, 5). Each sequence consists of sandy and clayey silts of overbank floods, capped by poorly to welldeveloped, organic-rich paleosols of floodplains. Thus, as rising sea level continued to drive aggradation upstream, streambeds aggraded, and as the channels filled with sediment, floodplains accreted by periodic overbank flooding. Eventually, a minimum gradient threshold was reached, after which the channel was reincised, or a new channel created, temporarily bypassing the floodplain and thus allowing soils to develop. Rapid accretion kept the channels relatively shallow, so as the channels refilled with sediment, overbank flooding resumed and the sequence repeated (Wright and Marriott 1993). Thus, although the allogenic driver of sea-level rise was relatively continuous (though variable in rate), the response of the fluvial systems, aggradation, occurred in an episodic manner, controlled in part by autogenic thresholds. When the rate of sea-level rise slowed, the rate of aggrada- tion also slowed, allowing longer periods of floodplain stability and soil development before a cycle of overbank flooding began again, suggested by the presence of fewer and thicker depositional sequences and more well-developed paleosols in the upper parts of the sections.

The number, thickness, and frequency of these overbank flooding sequences vary between drainages and between reaches of each drainage, although some depositional layers or surfaces can be traced laterally for tens to hundreds of meters. The downstream control of continuously rising base level likely interacted in a complex manner with upstream controls such as water and sediment availability from source areas, resulting in complex responses causing out-of-phase periods of erosion, deposition, or rejuvenation in various reaches, despite the overall aggradational mode of the system. Some, perhaps many, of the observed scour or aggradational sequences may have been caused by short-term allogenic forcings, in particular flood events caused by large storms.

\section{Historical Sedimentation}

Much of the alluvial sedimentary record on SCI has been obscured, altered, or obliterated by massive erosion and sedimentation resulting from widespread slope denudation in the late 19th century caused by overgrazing, drought, and catastrophic floods (Brumbaugh 1980, Perroy et al. 2012). Sheep ranching began on SRI in 1844 and on SCI in 1853, and by the 1860 s to 1870 s as many as 50,000 sheep grazed on each island (Schuyler 1993, Allen 1996). Sheep are generalist herbivores, eating almost any plants available to them (Van Vuren and Coblentz 1987). Overgrazing stripped the island's hillslopes of vegetation, greatly increasing surface soil erosion, and reduced or eliminated some plant communities, allowing other species with poorer soil-stabilizing qualities to colonize, or simply exposing large areas of bare ground. Trampling reduced annual cover and disrupted soil surfaces, hampering future growth of annuals, thus further contributing to erosion and food source losses (Webb and Stielstra 1979). Several periods of intense drought occurred during the late 19th century, and livestock loss due to starvation was documented on San Miguel, San Nicolas, Santa Rosa, and Santa Cruz Islands (Johnson 1980). 
Catastrophic flooding caused by the storm of 1861-1862 that dropped as much as $1650 \mathrm{~mm}$ of rain on southern California in a 45-day period is reported to have initiated arroyo cutting in a number of locations (Engstrom 1996), and it probably greatly accelerated arroyo incision on SCI that was already underway.

When the Vail and Vickers Company purchased Santa Rosa Island in 1901, they removed the sheep and converted the island to a cattle ranch (Allen 1996). In subsequent years, livestock management greatly reduced grazing stresses, and in turn, hillslope erosion, on that island. In contrast, tens of thousands of feral sheep continued to roam freely on SCI, denuding hillslopes, until their removal in the 1980s (Brumbaugh 1980, Van Vuren and Coblentz 1987, Schuyler 1993, Klinger et al. 1994). In the 20th century, ranchers on SCI erected fences to exclude feral sheep from specific areas (Howarth and Laughrin 2009), notably the Central Valley, including Christy and Sauces Canyons, and the isthmus. The most severely impacted areas were the north ridge from Cañada del Puerto westward, and southern SCI including Pozo, Laguna, Willows, and Coches Prietos Canyons (Van Vuren and Coblentz 1987). It is therefore no coincidence that these canyon floors are filled with thick layers of coarse-grained sediment, originating not only from the late 19th century but also from continued severe hillslope erosion throughout most of the 20th century that has buried or otherwise obscured much of the sedimentary evidence of sea-level-driven aggradation on SCI.

\section{Conclusions}

This study contributes a more detailed understanding of the primary late PleistoceneHolocene fluvial system response to climate and sea-level changes on SCI, as well as mapping the shoreline migration around the island for an important period in Channel Islands prehistory. Because sea-level rise drove nearly continuous aggradation in the canyons of SCI, plant, animal, and human remains and artifacts that are of interest to paleontologists, archaeologists, paleoecologists, and geologists are often preserved. Moreover, the deposits provide an important sedimentary context that allows researchers to (1) determine relative or approximate ages of artifacts and specimens that may not otherwise be directly datable and (2) characterize the environment that existed at various times in the late Quaternary.

During periods of low or lowering sea level, erosion was the dominant mode in the canyons of SCI, and much of the sediment that had accumulated in valley floors was transported off the island and onto the shelf. When sea level rose, the streams' ability to transport sediment was reduced, resulting in aggradation that progressed from the shelf upstream into the canyons. This cycle of erosion and aggradation in response to glacialinterglacial sea-level cycles has been repeated numerous times during the Quaternary, although sedimentary evidence of only the most recent cycle remains on SCI.

Differences in the nature and extent of alluvial exposures in different canyons on SCI, as well as relative to those on SRI, are due to differences in the topography, geology, and ranching history of the 2 islands. The steep topography and high relief of Santa Cruz Island, much of which is underlain by plutonic, volcanic, and metamorphic rocks, typically produce sandy and gravelly slope wash and alluvium. These sediments generally are not cohesive enough to form tall streambanks or arroyo walls, nor do they typically retain or preserve datable materials such as charcoal, wood fragments, or land snails. Full sequences of finer-grained alluvium were only preserved in Christy, Sauces, and Pozo Canyons due to their gentler gradients, more erodible underlying geology, and the shallow basin of the Santa Cruz Channel into which Christy and Sauces Canyons drain, which may have periodically acted as a local base level that further facilitated sediment retention within those canyons.

On both SCI and SRI, posttransgression rejuvenation of the fluvial systems caused reincision of alluvium and arroyo development. On SRI, hillslope and floodplain stabilization was facilitated by removal of sheep from the island in the early 1900s. With less erosion occurring on the hillslopes, runoff had more erosive power in the channels, which allowed the arroyos to substantially widen and deepen during the 20th century. On SCI, however, continued vegetation stripping by thousands of feral sheep allowed hillslope erosion to continue at accelerated rates until the 1980s, delivering additional sediment to the canyon 
bottoms and burying older alluvium, particularly in Pozo, Laguna, and Willows Canyons.

\section{ACKNOWLEDGMENTS}

This study was supported by the Climate and Land Use Change Program of the U.S. Geological Survey (USGS) and is a contribution to the Geologic Records of High Sea Levels Project. We greatly appreciate the guidance and support of our colleague, Dr. Daniel R. Muhs, who encouraged, facilitated, and assisted us in this study. Sincere thanks go to The Nature Conservancy and the UCSB Santa Cruz Island Reserve, especially Dr. Lyndal Laughrin, for field access and logistical support. Radiocarbon age determinations were processed and analyzed by Dr. Jack McGeehin (USGS, retired), whose friendship and analytical support we greatly appreciate. Reviews by Dan Muhs, Janet Slate, and 2 anonymous reviewers greatly improved the manuscript and are much appreciated. Any use of trade, firm, or product names is for descriptive purposes only and does not imply endorsement by the U.S. Government.

\section{Literature Cited}

Allen, K.B. 1996. Ranching on Santa Rosa Island. Pages 9-15 in K.B. Allen, editor, Island of the cowboysSanta Rosa Island. Santa Cruz Island Foundation Occasional Paper No. 7, Santa Barbara, CA.

Anderson, R.L., R. Byrne, and T. Dawson. 2008. Stable isotope evidence for a foggy climate on Santa Cruz Island, California at $\sim 16,600$ cal. yr. B.P. Palaeogeography, Palaeoclimatology, Palaeoecology 262:176-181.

Anderson, R.S., S. Starratt, R.M.B. Jass, and N. Pinter 2010. Fire and vegetation history on Santa Rosa Island, Channel Islands, and long-term environmental change in southern California. Journal of Quaternary Science 25:782-797.

BeHL, R.J. 1995. Sedimentary facies and sedimentology of the late Quaternary Santa Barbara Basin, site 893. Pages 295-308 in J.P. Kennett, J.G. Baldauf, and M. Lyle, editors, Proceedings of the Ocean Drilling Program, Scientific Results, volume 146 (part 2). Ocean Drilling Program, College Station, TX.

Boyle, T., and L. Laughrin. 2000. California's Santa Cruz Island weather. Pages 93-99 in D.R. Browne, K.L. Mitchell, and H.W. Chaney, editors, Proceedings of the Fifth California Islands Symposium. United States Department of the Interior, Minerals Management Service Publication MMS 99-0038.

Brumbaugh, R.W. 1980. Recent geomorphic and vegetal dynamics on Santa Cruz Island, California. Pages 139-158 in D.M. Power, editor, The California Islands: proceedings of a multidisciplinary symposium. Santa Barbara Museum of Natural History, Santa Barbara, CA.
BuLL, W.B. 1991. Geomorphic responses to climatic change. Blackburn Press, Caldwell, NJ.

Carignan, K.S., L.A. Taylor, B.W. Eakins, R.R. Warnken, E. Lim, ANd P.R. MEDLEy. 2009. Digital elevation model of Santa Barbara, California: procedures, data sources and analysis. NOAA Technical Memorandum NESDIS NGDC-29, United States Department of Commerce, Boulder, CO.

Clark, J., J.X. Mitrovica, And J. Alder. 2014. Coastal paleogeography of the California-Oregon-Washington and Bearing Sea continental shelves during the latest Pleistocene and Holocene: implications for the archaeological record. Journal of Archaeological Science 52:12-23.

Clark, P.U., AND A.C. Mix. 2002. Ice sheets and sea level of the Last Glacial Maximum. Quaternary Science Reviews 21:1-7.

DibbleE, T.W., JR. 2001a. Geologic map of western Santa Cruz Island, Santa Barbara, California. Dibblee Geological Foundation map DF-77, scale 1:24,000.

Dibblee, T.W., Jr. 2001b. Geologic map of eastern Santa Cruz Island, Santa Barbara, California. Dibblee Geological Foundation map DF-78, scale 1:24,000.

Engstrom, W.N. 1996. The California storm of January 1862. Quaternary Research 46:141-148.

Glassow, M.A., O.A. Chadwick, R.L. Perroy, and J.T. HowarTh. 2009. Alluvial history and human prehistory in Pozo Canyon, Santa Cruz Island, California. Pages 53-65 in C.C. Damiani and D.K. Garcelon, editors, Proceedings of the 7th California Islands Symposium. Institute for Wildlife Studies, Arcata, CA.

Gordon, J.H., J.R. Boles, and P.W. Weigand. 2001. Geology of Santa Cruz Island: key to understanding the evolution of the Southern California Borderland. Pages 147-185 in G. Dunne and J. Cooper, compilers, Geologic excursions in southwestern California. Pacific Section SEPM Special Publication 89.

Hendy, I.L., T.J. Napier, and A. Schimmelmann. 2015. From extreme rainfall to drought: 250 years of annually resolved sediment deposition in Santa Barbara Basin, California. Quaternary International 387:3-12.

Howarth, J.T., and L.L. Laughrin. 2009. Many small becoming many large: understanding changes in cultural landscapes. Pages 89-98 in C.C. Damiani and D.K. Garcelon, editors, Proceedings of the 7th California Islands Symposium. Institute for Wildlife Studies, Arcata, CA.

Johnson, D.L. 1980. Episodic vegetation stripping, soil erosion, and landscape modification in prehistoric and recent historic time, San Miguel Island, California. Pages 103-121 in D.M. Power, editor, The California Islands: proceedings of a multidisciplinary symposium. Santa Barbara Museum of Natural History, Santa Barbara, CA.

Junak, S., T. Ayers, R. Scott, D. Wilken, and D. Young. 1995. A flora of Santa Cruz Island. Santa Barbara Botanic Garden, Santa Barbara, CA.

Junger, A. 1979. Maps and seismic profiles showing geologic structure of the northern Channel Islands platform, California Continental Borderland. U.S. Geological Survey Miscellaneous Field Investigations Report MF-991, scale 1:250,000.

Klinger, R.C., P.T. SChuyler, and J.D. Sterner. 1994. Vegetation response to removal of feral sheep from Santa Cruz Island. Pages 341-350 in W.L. Halvorson and G.J. Maender, editors, The Fourth California Islands Symposium: update on the status of 
resources. Santa Barbara Museum of Natural History, Santa Barbara, CA

MaCKIn, J.H. 1948. Concept of the graded river. Geological Society of America Bulletin 59:463-512.

Milne, G.A., And J.X. Mitrovica. 1996. Postglacial sealevel change on a rotating earth: first results from a gravitationally self-consistent sea-level equation. Geophysical Journal International 126:F13-F20.

Milne, G.A., AND J.X. Mitrovica. 2008. Searching for eustacy in deglacial sea-level histories. Quaternary Science Reviews 27:2292-2302.

Mitrovica, J.X., And G.A. Milne. 2003. On post-glacial sea level: I. General theory. Geophysical Journal International 154:253-267.

Muhs, D.R., K.R. Simmons, R.R. Schumann, L.T. Groves, S.B. DeVogel, S.A. Minor, and D. Laurel. 2014. Coastal tectonics on the eastern margin of the Pacific Rim: late Quaternary sea-level history and uplift rates, Channel Islands National Park, California, USA. Quaternary Science Reviews 105:209-238.

Muhs, D.R., K.R. Simmons, R.R. Schumann, and R.B. HALLEY. 2011. Sea-level history of the past two interglacial periods: new evidence from U-series dating of reef corals from south Florida. Quaternary Science Reviews 30:570-590.

Murray-Wallace, C.V., and C.D. Woodroffe. 2014. Quaternary sea-level changes: a global perspective. Cambridge University Press, New York, NY.

Peltier, W.R., AND R.G. Fairbanks. 2006. Global glacial ice volume and Last Glacial Maximum duration from an extended Barbados sea level record. Quaternary Science Reviews 25:3322-3337.

Perroy, R.L., B. Bookhagen, O.A. Chadwick, and J.T. HowarTH. 2012. Holocene and Anthropocene landscape change: arroyo formation on Santa Cruz Island, California. Annals of the Association of American Geographers 102:1229-1250.

Pinter, N., S.B. Lueddecke, E.A. Keller, and K.R. Simmons. 1998. Late Quaternary slip on the Santa Cruz Island fault, California. Geological Society of America Bulletin 110:711-722.

Pinter, N., A.C. Scott, T.L. Daulton, A. Podoll, C. KoeberL, R.S. Anderson, and S.E. Ishman. 2011. The Younger Dryas impact hypothesis: a requiem. Earth Science Reviews 106:247-264.

Pinter, N., AND C. Sorlein. 1991. Evidence for latest Pleistocene to Holocene movement on the Santa Cruz Island fault, California. Geology 19:909-912.

Pinter, N., C. Sorlein, ANd A.T. Scott. 2003. Faultrelated fold growth and isostatic subsidence, California Channel Islands. American Journal of Science 303:300-318.

Porebski, S.J., and R.J. Steel. 2006. Deltas and sealevel change. Journal of Sedimentary Research 76: 390-403.

Posamentier, H.W., G.P. Allen, D.P. James, and M. TESSON. 1992. Forced regressions in a sequence stratigraphic framework: concepts, examples, and exploration significance. AAPG Bulletin 76:1687-1709.

Reimer, P.J., E. Bard, A. Bayliss, J.W. Beck, P.G. Blackwell, C. Bronk Ramsey, P.M. Grootes, T.P. GuILderSON, H. HaFLIDASON, I. HajdaS, ET AL. 2013. IntCal13 and Marine13 radiocarbon age calibration curves 0-50,000 years cal BP. Radiocarbon 55:1869-1887.

Schimmelmann, A., C.B. Lange, and B.J. Meggers. 2003. Palaeoclimatic and archaeological evidence for a 200-yr recurrence of floods and droughts linking
California, Mesoamerica and South America over the past 2000 years. Holocene 13:763-778.

Schumann, R.R., J.S. Pigati, and J.P. McGeehin. 2016. Fluvial system response to late PleistoceneHolocene sea-level change on Santa Rosa Island, Channel Islands National Park, California. Geomorphology 268:322-340.

Schumm, S.A. 1977. Geomorphic thresholds and complex response of drainage systems. Pages 299-310 in M. Morisawa, editor, Fluvial geomorphology. State University of New York, Binghamton, NY.

Schumm, S.A. 1993. River response to baselevel change: implications for sequence stratigraphy. Journal of Geology 101:279-294.

Schumm, S.A., and G.R. Brakenridge. 1987. River responses. Pages 221-240 in W.F. Ruddiman and H.E. Wright Jr., editors, North America and adjacent oceans during the last deglaciation. The geology of North America, volume K-3. Geological Society of America, Boulder, CO.

Schuyler, P. 1993. Control of feral sheep (Ovis aries) on Santa Cruz Island, California. Pages 443-452 in F.G. Hochberg, editor, Third Channel Islands Symposium: recent advances in research on the California Islands. Santa Barbara Museum of Natural History, Santa Barbara, CA.

Stuiver, M., And P.J. Reimer. 1993. Extended ${ }^{14} \mathrm{C}$ database and revised CALIB radiocarbon calibration program. Radiocarbon 35:215-230.

Suter, J.R., AND H.L. Berryhill JR. 1985. Late Quaternary shelf-margin deltas, northwest Gulf of Mexico. AAPG Bulletin 69:77-91.

Van Vuren, D., and B.E. Coblentz. 1987. Some ecological effects of feral sheep on Santa Cruz Island, California, USA. Biological Conservation 41:253-268.

Weaver, D.W. 1969. Paleogeographic implications and geologic history. Pages 115-124 in D.W. Weaver, D.P. Doerner, and B. Nolf, editors, Geology of the northern Channel Islands. Special publication, Pacific Sections, AAPG and SEPM.

Weaver, D.W., G. Griggs, D.V. McClure, and J.R. McKey. 1969. Volcaniclastic sequence, south central Santa Cruz Island. Pages 85-90 in D.W. Weaver, D.P Doerner, and B. Nolf, editors, Geology of the northern Channel Islands. Special publication, Pacific Sections, AAPG and SEPM.

Weaver, D.W., AND G.L. Meyer. 1969. Stratigraphy of northeastern Santa Cruz Island. Pages 95-104 in D.W. Weaver, D.P. Doerner, and B. Nolf, editors, Geology of the northern Channel Islands. Special publication, Pacific Sections, AAPG and SEPM.

WebB, R.H., and S.S. Stielstra. 1979. Sheep grazing effects on Mojave Desert vegetation and soils. Environmental Management 3:517-529.

Wright, V.P., and S.B. Marriott. 1993. The sequence stratigraphy of fluvial depositional systems: the role of floodplain sediment storage. Sedimentary Geology 86:203-210.

Yokoyama, Y., K. Lambeck, P. DE Dekhar, P. Johnston, AND L.K. Fifield. 2000. Timing of last glacial maximum from observed sea-level minima. Nature 406: $713-716$.

Received 3 March 2017

Revised 4 August 2017

Accepted 10 August 2017

Published online 28 November 2017 